\title{
PARASITOIDISM OF CHALCIDID WASPS (HYMENOPTERA, CHALCIDIDAE) ON Philornis sp. (DIPTERA, MUSCIDAE)
}

\author{
COURI, M. S. ${ }^{1,4}$, TAVARES, M. T. ${ }^{2}$ and STENZEL, R. R. ${ }^{3}$ \\ ${ }^{1}$ Departamento de Entomologia, Museu Nacional, Quinta da Boa Vista, \\ CEP 20940-040, Rio de Janeiro, RJ, Brazil \\ ${ }^{2}$ Departamento de Ciências Biológicas, Universidade Federal do Espírito Santo, \\ Av. Marechal Campos, 1468, Maruípe, CEP 29040-090, Vitória, ES, Brazil \\ ${ }^{3}$ Rua Dr. Caetano de Faria Castro, 46/203, Campo Grande, CEP 23052-010, Rio de Janeiro, RJ, Brazil \\ ${ }^{4}$ Research fellow of Conselho Nacional de Desenvolvimento Científico e Tecnológico, CNPq \\ Correspondence to: Márcia Souto Couri, Museu Nacional, Quinta da Boa Vista, CEP 20940-040, \\ Rio de Janeiro, RJ, Brasil, e-mail: mcouri@attglobal.net \\ Received November 17, 2004 - Accepted January 25, 2005 - Distributed May 31, 2006 \\ (With 8 figures)
}

\begin{abstract}
Philornis Meinert larvae are known as parasites of birds, with coprophagous, semi-hematophagous or hematophagous habits. Biological data of the larvae of the fifty described species are still scarcely known. Here we describe some aspects of the parasitism of a species of Philornis on Thalurania glaucopis Gmelin (Trochilidae) and record two species of Chalcididae (Hymenoptera) parasitoids, Conura annulifera (Walker, 1864) and Brachymeria podagrica (Fabricius, 1787), reared from Philornis puparia.
\end{abstract}

Keywords: Thalurania glaucopis, Conura annulifera, Brachymeria podagrica, parasitoidism, association.

\section{RESUMO}

\section{Parasitoidismo de vespas Chalcididae (Hymenoptera, Chalcididae) sobre Philornis sp. (Diptera, Muscidae)}

As larvas de Philornis Meinert são conhecidas como parasitas de aves, com hábitos coprófagos, semihematófagos ou hematófagos. Dados biológicos das larvas das 50 espécies descritas são ainda pouco conhecidos. Aqui são descritos alguns aspectos do parasitismo de uma espécie de Philornis em Thalurania glaucopis Gmelin (Trochilidae) e duas espécies parasitóides de Chalcididae (Hymenoptera), Conura annulifera (Walker, 1864) e Brachymeria podagrica (Fabricius, 1787) que emergiram de pupários de Philornis sp. são registradas.

Palavras-chave: Thalurania glaucopis, Conura annulifera, Brachymeria podagrica, parasitodismo, associação.

\section{INTRODUCTION}

Philornis species are muscids known for their interesting larval habits, as they are parasites of bird nestlings in three different types of associations - free living in the nests with coprophagous habits, free living in the nest, with semi-hematophagous habits or subcutaneous bloodfeeders as the majority of the species with known larval habits.
The pupae occur in the nest, in most cases inside a frothy cocoon and the adults are free living (Couri, 1999).

Biological data of the larvae of the fifty described species are still scarcely known. The nature of the association with the bird species is known only to 28 Philornis species. Teixeira (1999) supplied a list of the host bird species recorded until that year. 
The main aim of this paper is to record new data of Chalcididae (Hymenoptera) parasitoidism on a species of Philornis.

\section{MATERIAL AND METHODS}

RNS collected the material used in this study in January 2004 in an area called "arboreto" in the Botanical Gardens in Rio de Janeiro (RJ, Brazil). A hummingbird Thalurania glaucopis Gmelin (Trochilidae) nest with two eggs was found in Guarea kunthiana A Juss (Meliaceae). After a period of 15 days of incubation, the two nestlings were born (from 7 to $22 \mathrm{Dec}, 2003$ ). They were infested by Philornis intradermical larvae observed in their heads and necks (Fig. 1).

The nestlings abandoned the nest after 23 days on 14 Jan, 2004. The nest was collected, maintained in a sealed bottle, and observed daily. After seven days, a wasp $8.0 \mathrm{~mm}$ long emerged from the pupa (Figs. 2 and 3). During the subsequent days, a total of 11 wasps emerged. The nest was carefully investigated and 22 other puparia were found (Fig. 4), but no more wasps and no Philornis adults.

The collected material was then transported to the Diptera laboratory at Museu Nacional, Rio de Janeiro, Brazil for study purposes.

Among the puparia, two entire pupae of Philornis were found. One of them was clarified with potassium hydroxide and dissected. In the interior of the pupa the same species of wasp was found (Fig. 5).

\section{RESULTS AND DISCUSSION}

The emerged wasps belong to Conura annulifera (Walker, 1864) (Chalcididae). Burks (1960) described Spilochalcis ornitheia, a junior synonymy of the former, and recorded it as reared

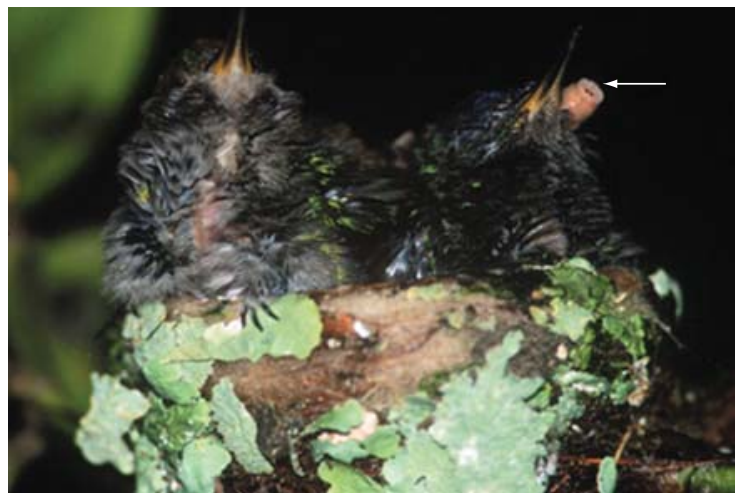

Fig. 1 - Nestlings of Thalurania glaucopis Gmelin, 1788 infested by Philornis sp larvae.

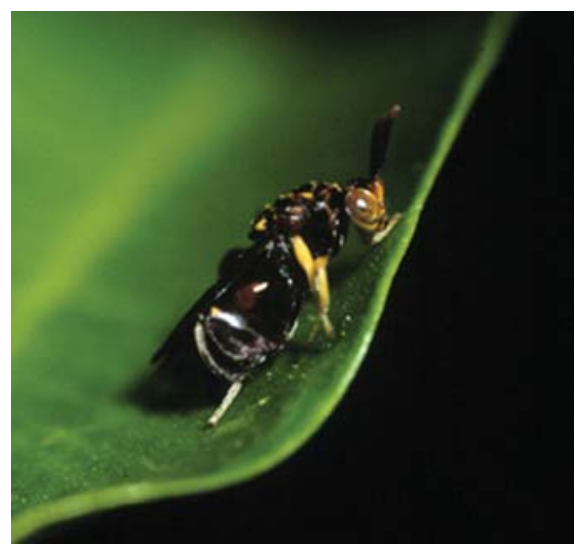

Fig. 2 - Conura annulifera (Walker, 1864) (Chalcididae) recently emerged from Philornis sp. pupa. 


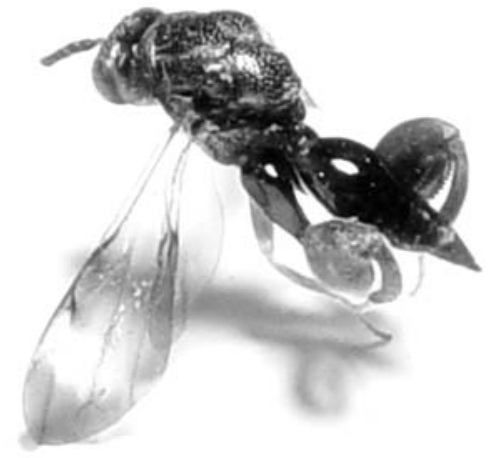

Fig. 3 - Conura annulifera (Walker, 1864) (Chalcididae): dried specimen.

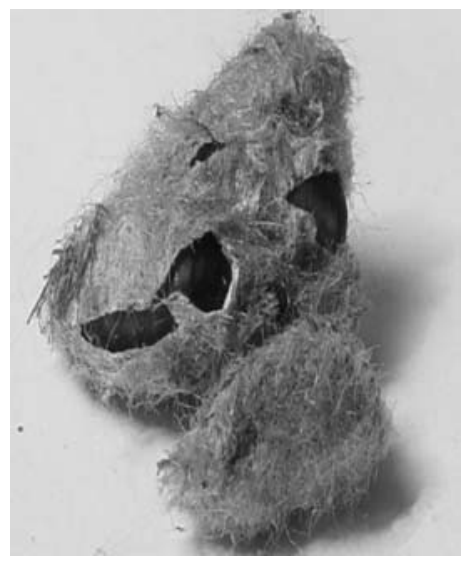

Fig. 4 - Puparia of Philornis sp found in nest of Thalurania glaucopis.

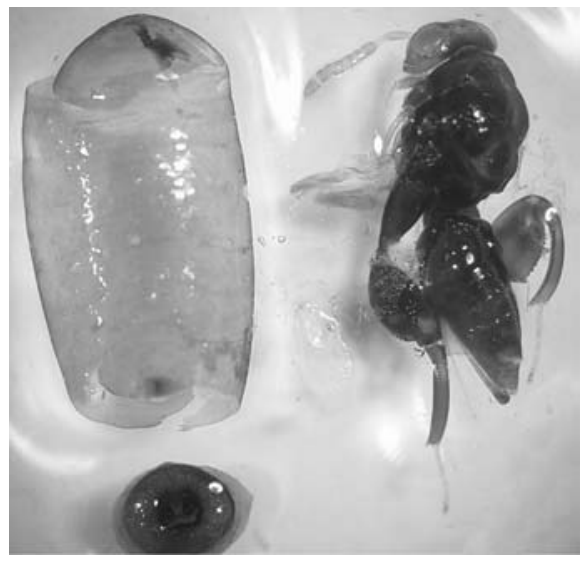

Fig. 5 - Puparium of Philornis sp and the adult wasp found in its interior. 
from Philornis puparia collected in bird nests in Trinidad (West Indies). Delvare (1992) assembled fourteen species of Conura in the discolor group, including C. annulifera, and no more host records or biological data are available to them. Only this Conura species is known to be associated to Muscidae (Diptera).

Although it was not possible to certify the identification of the Philornis species, as only its puparium and pupae were available, the dissection of the pupae (Fig. 6) showed the morphology of the posterior spiracle, the " $\mathrm{C}$ " shaped posterior spiracular slits (Fig. 7) and the cephalofaringeal skeleton (Fig. 8). This morphology shows that this species could be $P$. insularis Couri, 1983. Sick (1977) recorded a number of 64 adults of this species collected from one nest of Thalurania glaucopis and another 16 larvae collected directed from the nestlings, making a total of 80 Philornis specimens from only one nest. He also mentioned that Philornis species are severe parasites of hummingbirds.

The available data on Philornis species life cycle are very scarce. In Philornis torquans

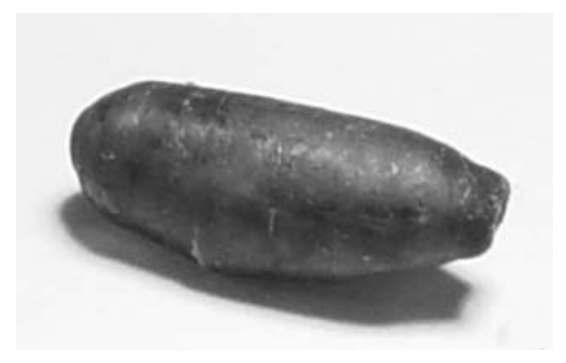

Fig. 6 - Pupa of Philornis sp.

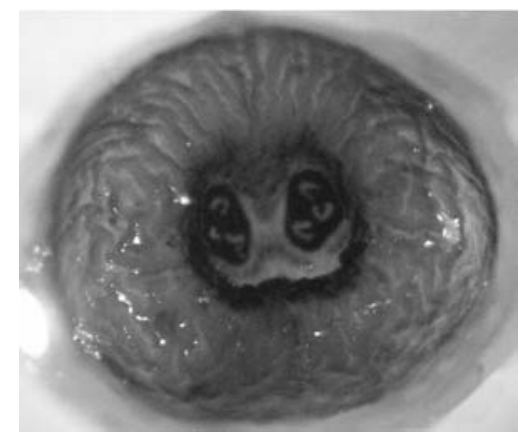

Fig. 7 - Posterior spiracle and posterior spiracular slits of the puparium of Philornis sp.

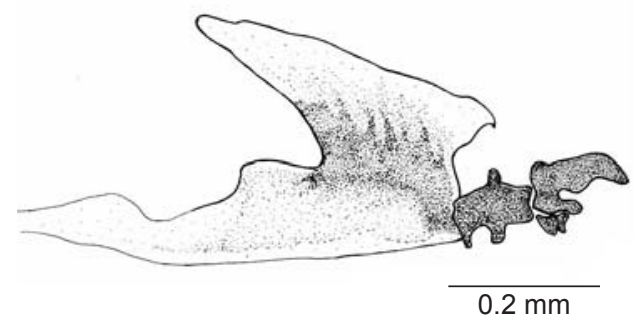

Fig. 8 - Cephalofaringeal skeleton of the puparium of Philornis sp. 
(Nielsen, 1913) the pupa lasts 5-6 days and in P. angustifrons (Loew, 1861), 11 days; there are also records of a total of 15 days from the egg to the emergence of the adult (Skidmore 1985; Couri, 1991). Couri et al. (in press) presented biological data on Philornis seguyi Garcia, 1952 collected from six species of birds in Buenos Aires, Argentina. They recorded the infestation of the chicks as early as $24 \mathrm{~h}$ after hatching. The estimation of the larval period was five to seven days and from the pupae to the emergence, approximately 14 to 16 days. The pupae were enclosed in a cocoon.

In the present study, although we can not be precise about when Philornis sp. infested the nestlings, when the young birds abandoned the nest (23 days after hatching) and the pupae were already inside the nest, seven days passed until the emergence of the first wasp, which is a longer period than is known for Philornis.

The chalcidid parasitoids of Diptera (e.g. Brachymeria) attack host larvae or pupae. In this case, the parasitoid female should have attacked the larvae as they are more exposed. In the pupa stage, the Philornis stay at the bottom of the nest, under the nestlings, where it should be more difficult to be attacked by a parasitoid female. Delvare (1995) stated that, under optimal conditions and depending upon the size of the species, the development from egg to adult requires 16 to 30 days. This period is compatible to that of a bird egg hatching to wasps emerging (30 days).

Associations of Philornis species with wasps and birds, which are different from parasitoidism, were recorded and discussed (Dodge, 1968; Haverschmidt, 1957). In these cases, the wasps were predacious and captured adults of Diptera, including Philornis to feed their larvae, protecting, to a certain extent, the bird species from the Philornis parasitism.

When the second author (MTT) was studying the chalcidids deposited in the Hymenoptera collection of the United States National Museum of Natural History (USNM - Washington, USA), he found one specimen of Brachymeria podagrica (Fab., 1787) (Chalcididae), which was reared from Philornis puparia, also from Trinidad, with the following label data: "Chalcid parasite 'CC', ex: pupa \#1 Philornis sp. 'K', ex: nest of Synallanix albescens, Sangre Grande, Trinidad, N.I. 28/v/58. T. Aitken". B. podagrica is a cosmopolitan and very common species that has been recorded to attack more than twenty species of cyclorraphous Diptera.

This is the only two parasitic Hymenoptera species known to attack Phillornis.

Acknowledgments - MSC is grateful to the "Conselho Nacional de Desenvolvimento Científico e Tecnológico, CNPq" for a grant (nr. 300386-80 ZO). MTT is grateful to E. E. Grissell and the Office of Fellowships and Grants (Smithsonian Institute, Washington) for the advice, grant and opportunity to visit their collection. Dimitrius C. Stenzel took photos 1-2 and Antônio Clóvis Brito de Araújo (Museu Nacional) photos 3-8.

\section{REFERENCES}

BURKS, B. D., 1960, A Spilochalcis parasitic on flies that infest birds nests (Hymenoptera, Chalcididae). Acta Hymenopterologica, 1(2): 95-97.

COURI, M. S., 1991, Philornis carinatus Dodge, 1968 (Diptera, Muscidae) data on morphology, biology and taxonomy. Revista Brasileira de Entomologia, 35: 109-112. Curitiba.

COURI, M. S.,1999, Myiasis caused by obligatory parasites. Ia. Philornis Meinert (Muscidae): pp. 51-70. In: J. H. Guimarães \& N. Papavero, Myiasis in man and animals in the Neotropical Region. Bibliographic database, 308p., Editora Pleaide, FAPESP, São Paulo.

COURI, M. S., RABUFFETTI, F. L. \& REBOREDA J. C., in press, Descriptions and new data on Philornis seguyi Garcia (Diptera, Muscidae). Brazilian Journal of Biology, São Paulo.

DODGE, H. R., 1968, Some new and little-known species of Philornis (Diptera: Muscidae). Journal of the Kansas Entomological Society, 41: 155-164. Kansas.

DELVARE, G., 1992, A reclassification of the Chalcidini with a checklist of the New World species, pp. 119-441. In: G. Delvare \& Z. Boucek. (eds.), On the New World Chalcididae (Hymenoptera). Memoirs of the American Entomological Institute, 53: 1-466. Gainesville.

DELVARE, G., 1995, Chalcididae, pp. 289-298. In: P. E. Hanson \& I. Gauld (eds.), The Hymenoptera of Costa Rica, 893p. Oxford Univ. Press, Oxford.

HAVERSCHMIDT, F., 1957, Nachbarschsft Von Vögelnesten und Wespernnestern in Surinam. Journal of Ornithology, 98: 389-396.

SICK, H., 1977, Beija-flores: Trochilidae: 78. In. Ornitologia Brasileira. Nova Fronteira.

SKIDMORE, P., 1985, The biology of the Muscidae of the world. Series Entomologica 29: 1-550.

TEIXEIRA, D. M., 1999, Myiasis caused by obligatory parasites. Ib. General observations on the biology of the species of the genus Philornis Meinert, 1890 (Diptera, Muscidae). In: J. H. Guimarães \& N. Papavero, Myiasis in man and animals in the Neotropical Region. Bibliographic database, 308p., Editora Pleaide, FAPESP, São Paulo. 